\title{
Radiosensitivity and Chromosome Numbers in Strain L Mouse Cells in Tissue Culture
}

\author{
J. E. TILL \\ Physics Division, The Ontario Cancer Institute, and Department of Medical Biophysics, \\ University of Toronto, Toronto, Ontario
}

\section{INTRODUCTION}

The lethal effects of ionizing radiations on cells may be either genetic or nongenetic in origin and, if genetic, may be classified as dominant or recessive. If the radiosensitivity of an organism depends on its ploidy, it may be inferred that genetic damage is involved (1). Where such a dependence has been found, the relative importance of recessive and dominant lethal effects appears to account for the radiosensitivities observed $(2,3)$. Since it has been postulated that the loss of proliferative capacity by mammalian cells is principally the result of damage to chromosomes $(4,5)$, it is of interest to test for a ploidy effect in mammalian cells. An approach to this problem may be made by using strain L mouse cells in tissue culture, since a number of independently maintained cultures of this cell line have been found to differ considerably in chromosome number $(6,7)$. In this paper, the radiation survival curves for several selected L-cell lines differing in chromosome number are compared.

\section{MATERIALS AND METHODS}

Cells

The cell lines used are listed in Table I. The origin of each line is indicated in the table. The lines referred to as L 1 and L 3 are sublines of NCTC clone 929 of Earle's strain L of the mouse (8). The chromosome complement of these sublines, as well as that of the cell lines MCN and AMK 2-2, has been described by Rothfels et al. $(6)$.

Chromosomal and transplantation studies $(6,9)$ have shown that the MCN and AMK 2-2 lines are indistinguishable from L-cells and that these lines were probably established because of contamination of cell cultures with L-cells. It should be emphasized that the nomenclature in Table I has been adopted only in this laboratory and is primarily designed for convenience in distinguishing lines of the L-cell type having different origins. 


\section{TABLE I}

Mean Chromosome Number, $D_{0}$, and Origin of the L-Cell Lines Used

\begin{tabular}{|c|c|c|c|}
\hline Cell line & $\begin{array}{c}\text { Mean chromosome } \\
\text { number }\end{array}$ & $D_{0}(\operatorname{rads})^{\mathrm{a}}$ & Origin \\
\hline L 53 & 53 & $278 \pm 16$ & Derived from strain MCN. \\
\hline L 60 & 60 & $290 \pm 19$ & Derived from strain AMK 2-2. \\
\hline L 3 & 69 & $283 \pm 17$ & $\begin{array}{l}\text { Derived from NCTC clone } 929 \text { of } \\
\text { Earle's strain L. }\end{array}$ \\
\hline L 1 & 81 & $278 \pm 28$ & $\begin{array}{l}\text { Derived from NCTC clone } 929 \text { of } \\
\text { Earle's strain L. }\end{array}$ \\
\hline L 109 & 109 & $270 \pm 12$ & $\begin{array}{l}\text { Derived from a clone isolated from } \\
\mathrm{L} 60 \text { cells treated with } 2 \times 10^{-7} \mathrm{gm} / \\
\text { ml colchicine. }\end{array}$ \\
\hline
\end{tabular}

a The standard deviation is given for each value.

The particular cell lines shown in the table were selected for this study because of their wide range of chromosome numbers. With the exception of $\mathrm{L} 53$, the lines studied were derived from single cells.

The cell line $\mathrm{L} 109$ was derived from a clone isolated from an $\mathrm{L} 60$ culture treated with $2 \times 10^{-7} \mathrm{gm} / \mathrm{ml}$ of colchicine (Laboratories Houde, Paris). This treatment induces polyploidy in cell cultures $(10)$.

Cells were routinely propagated in suspension cultures at $37^{\circ} \mathrm{C}$. Growth medium for stock cultures consisted of synthetic medium 1066 (11) supplemented with $10 \%$ horse serum and antibiotics. The cells were kept continuously in the logarithmic phase of multiplication by repeated subculture and under these conditions had a doubling time of about 20 hours.

Cell concentrations were determined by cell counts in a hemocytometer or by means of an electronic cell counter (Coulter Electronics Co., Chicago).

\section{Irradiation Procedure}

For irradiation, 6-ml aliquots of cells from a suspension culture were placed in stoppered $1.7 \times 9.5-\mathrm{cm} 12-\mathrm{ml}$ polyethylene tubes. These were irradiated one at a time in a Lucite holder having a wall thickness of $5 \mathrm{~mm}$, fixed in a horizontal position in air in a $37^{\circ} \mathrm{C}$ warm box situated beneath a 700 -curie $\mathrm{Co}^{60}$ source. The radiation beam passed through a port of 3-mm Lucite in entering the warm box.

Immediately before irradiation, the tubes were shaken vigorously in order to ensure that the cells were in suspension and adequately aerated. The cell concentration in the samples did not exceed $5 \times 10^{5}$ cells $/ \mathrm{ml}$; with a value of $1.1 \times 10^{-7} \mathrm{~mm}^{3}$ per cell per minute (12) taken as the respiration rate of L-cells at $37^{\circ} \mathrm{C}$, anoxia due to cellular utilization of oxygen would not arise in times under an hour. The irradiation time did not exceed 6 minutes, so that no changes in radiation sensitivity due to oxygen depletion $(13,14)$ should have occurred. 
Dosimetry was based on air ionization measurements made with a Victoreen condenser chamber calibrated by the U. S. National Bureau of Standards and by the National Research Council of Canada. Exposure dose measurements were made with the Victoreen chamber inserted into the Lucite sample holder, with the holder situated in air in the same position as for irradiation of the sample tubes. With a factor of $0.97 \mathrm{rad} / \mathrm{r}$ (15) assumed for $\mathrm{Co}^{60} \gamma$-rays, the absorbed dose rate in the samples was $330 \mathrm{rads} / \mathrm{min}$.

\section{Determination of the Number of Viable Cells}

Determinations of the number of cells capable of continued proliferation were made by colony counts, by the Puck-Marcus technique (16). Cell colonies were cultured in Pyrex petri dishes or in flint-glass prescription bottles (Brockway Glass Co., Brockway, Pennsylvania) in medium 1066 plus $10 \%$ or $20 \%$ serum. Several different selected sera, either equine or bovine, were used in the experiments. Sera were selected to yield a plating efficiency of greater than $50 \%$ (plating efficiency being defined as the percentage of cells capable of forming colonies under the particular culture conditions used).

In preliminary experiments with the L 60 line, it was found that, even with preselected sera, some variations in cell survival were observed if, after irradiation, the cells were incubated for colony counts in media containing different sera. Reasonably reproducible results could be obtained either by using the same serum for all experiments or by carrying out experiments with several different sera and pooling the results. Owing to limitations in the supply of any particular serum, the latter method was employed in the experiments to be reported below.

\section{Chromosome Counts}

For determinations of chromosome number a technique similar to that of Hsu and Klatt ( 7$)$ was followed. L-cells from a suspension culture were pretreated with $10^{-6} \mathrm{gm} / \mathrm{ml}$ of colchicine for 5 to 10 hours and then dilated by treatment with hypotonic saline, fixed in acetic-alcohol $(1: 3)$, stained with $2 \%$ acetic-orcein, and squashed gently on glass microscope slides. Chromosome counts on at least 50 cells were carried out for each cell line.

\section{RESULTS}

\section{Chromosome Number Distributions}

The chromosome complement of a typical L 60 cell is shown in Fig. 1. The total number of chromosomes per cell varies from cell to cell, and in Fig. 2 the results of chromosome number determinations carried out on each of the L-cell lines studied are summarized in graphical form. Each curve is a plot on a probability scale of the accumulated per cent of cells having a given chromosome number (or less), 


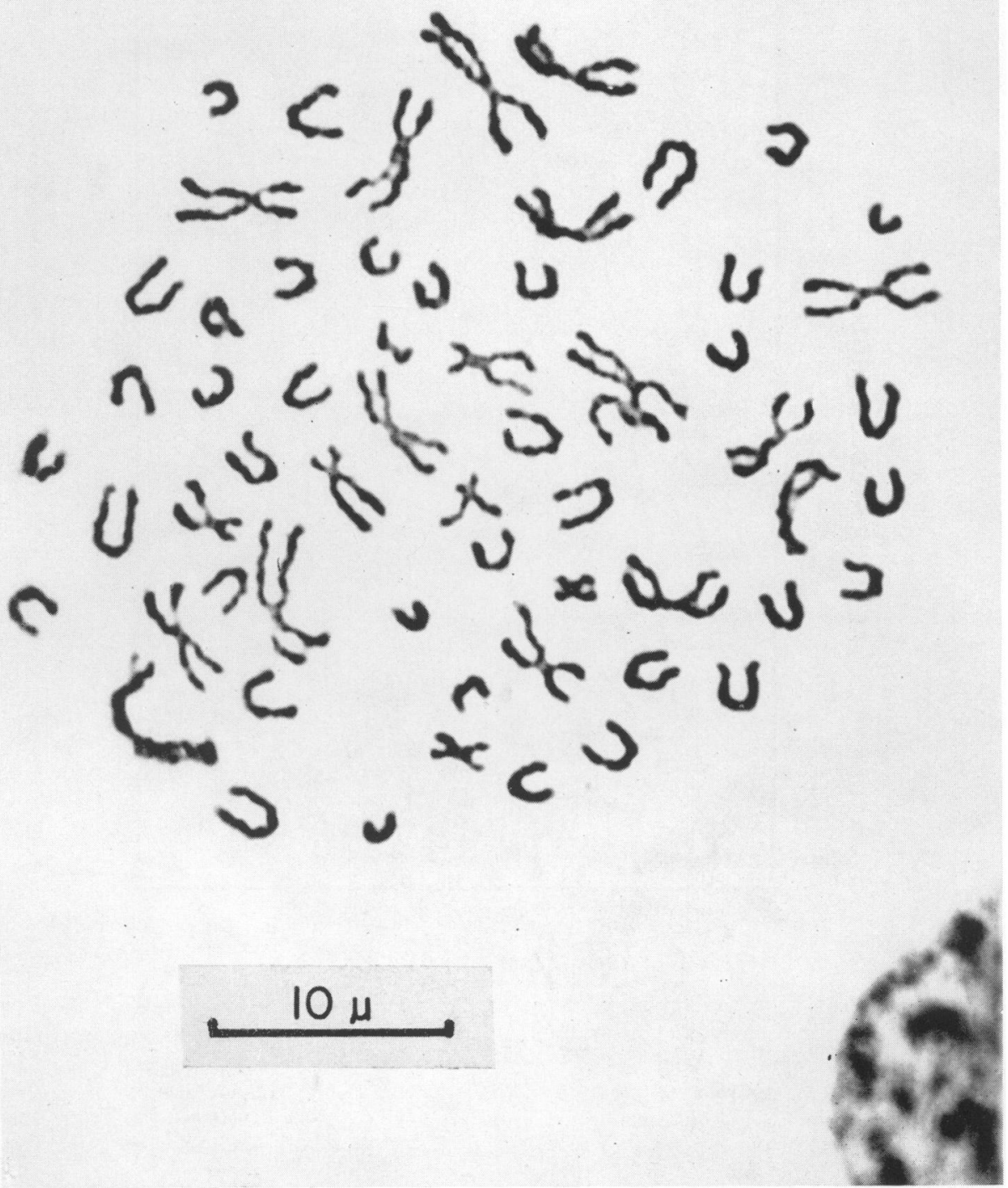

FIG. 1. The chromosome complement of a typical L 60 cell

as a function of chromosome number. Thus, for $\mathrm{L} 53$ cells, $2 \%$ of the cells sampled had chromosome numbers of 47 or less, $12 \%$ had 49 chromosomes or less, $18 \%$ had 50 chromosomes or less, etc. A straight line on a probability scale indicates that the cells are normally distributed in respect to chromosome number about a mean 


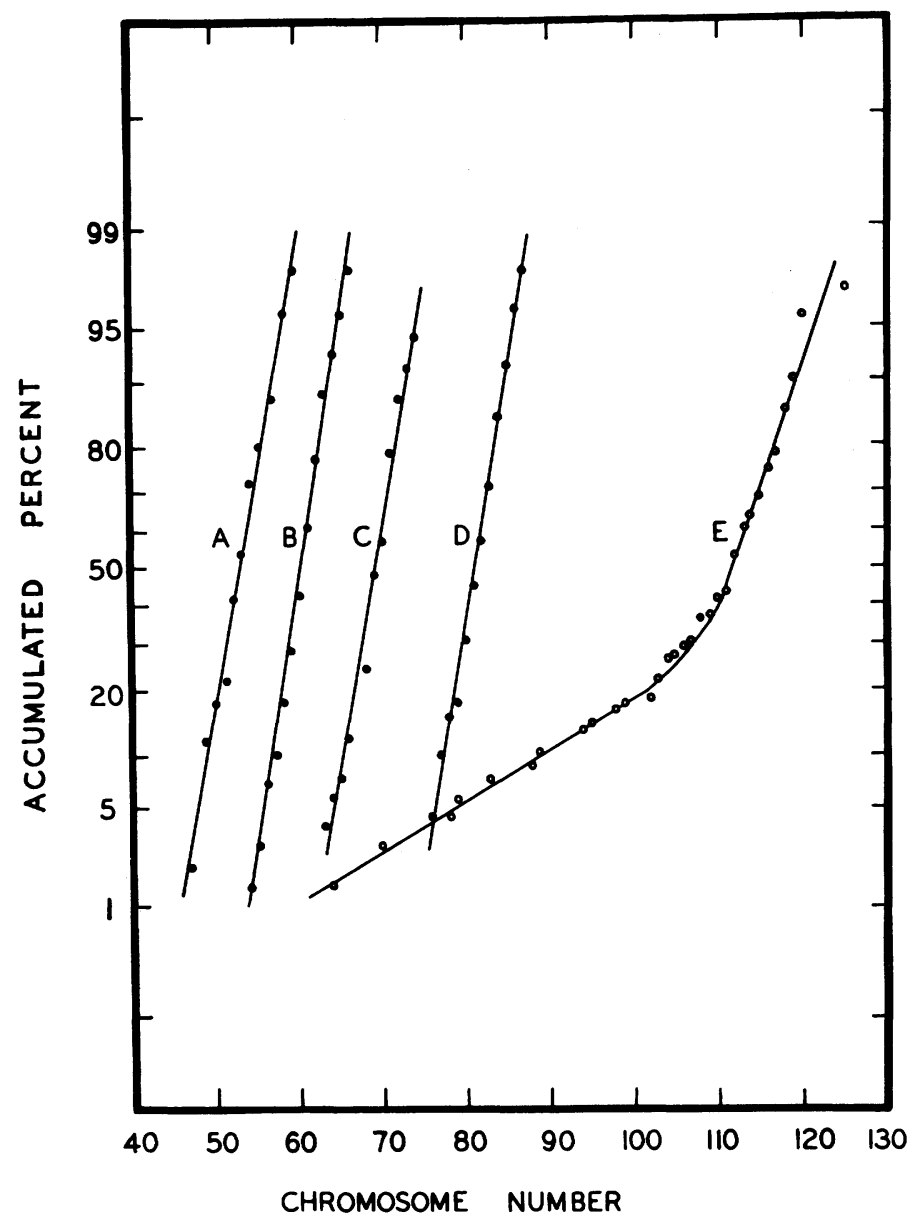

FIg. 2. A plot on a probability scale of the chromosome number distributions of five L-cell lines. Abcissa: chromosome number. Ordinate: accumulated per cent of cells having chromosome numbers less than or equal to the corresponding abscissa value. Curve $A$ : L 53. Mean chromosome number for 50 cells counted: 53. Curve $B: \mathrm{L}$ 60. Mean chromosome number, 213 cells: 60. Curve $C:$ L 3 . Mean chromosome number, 106 cells: 69. Curve $D:$ L 1 . Mean chromosome number, 117 cells: 81 . Curve $E$ : L 109. Mean chromosome number, 70 cells: 109.

number of chromosomes corresponding to the $50 \%$ ordinate on the probability plot. The mean number of chromosomes for each cell line, as well as the number of cells counted, is given in the figure caption. It may be noted that a straight-line relationship was not obtained for the L 109 cell line. The reason for this divergence from linearity is not known. For this cell line, the arithmetic mean chromosome number is given. Since the chromosome number for normal diploid mouse cells is 
40 (6), the mean chromosome number of the cell lines used ranges from a hypotriploid value of 53 to a hyperpentaploid value of 109 .

\section{Comparison of the Radiosensitivity of Different Lines}

Dose-effect curves were constructed for each cell line by determining the fraction of cells still capable of colony formation after different doses of $\mathrm{Co}^{60} \gamma$-rays. The results for three of the cell lines are shown in Fig. 3. It is evident that L-cell lines having a relatively low mean number of chromosomes (53 and 60 chromosomes) show a radiosensitivity not detectably different from that of a line having a relatively high mean number of chromosomes (109 chromosomes).

The dose-effect curves are of the multihit shape and thus may be characterized by two parameters $(17)$ : a mean lethal dose per hit $\left(D_{0}\right)$ which represents the dose required to reduce the surviving fraction by a factor $1 / e$ on the exponential portion of the curve; and an extrapolation number, represented by the ordinate value obtained when the exponential portion of the curve is extrapolated back to zero dose. Taken together, the data of Fig. 3 yield a $D_{0}$ of 280 rads and an extrapolation number of slightly less than 2 .

Values obtained for the $D_{0}$ for the different L-cell lines studied are included in Table I. There is no statistically significant difference between the $D_{0}$ values for the different lines.

\section{DISCUSSION}

The possible significance of the multihit type of radiation dose-effect curves obtained for mammalian cells has been reviewed by Puck $(5,18)$, who has summarized the evidence that the loss of proliferative capacity by irradiated mammalian cells is due to damage to chromosomes.

The observation that the $D_{0}$ for L-cells does not depend on chromosome number appears to indicate that nongenetic damage may also play a role. However, it is rather difficult to interpret the survival curves obtained with established tissueculture cell strains such as the L-cell lines used in the present work, mainly because they exhibit extensive heteroploidy, with variations in chromosome number within each line $(6,7)$. This could affect the radiosensitivity of these lines in two ways. First, the duplication of genes in such heteroploid cells would be expected to increase their tolerance to irradiation. The resulting reduction in the contribution of genetic damage to cell death would allow nongenetic damage to play a more important role in heteroploid cells than in euploid cells. Conversely, heteroploid cells may be monosomic for certain chromosomes. Recessive lethal damages in the monosomics would have a greater chance for expression than they would in the disomics. Thus, the presence of a critical monosomic in each of the cell lines used could suppress a ploidy effect $(19,20)$.

In cell populations containing a critical monosomic, one might expect a selection 


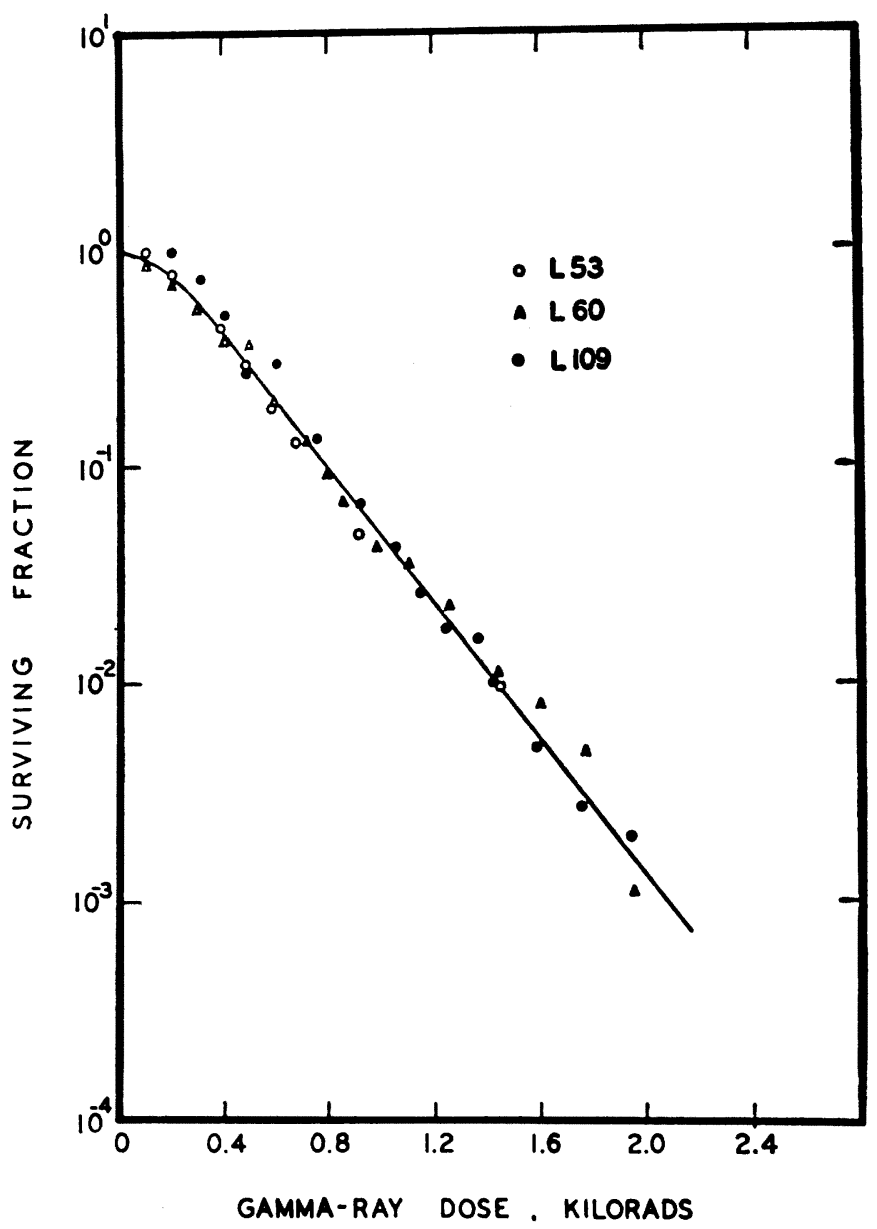

FIG. 3. Fraction of cells capable of colony formation after irradiation with various doses of $\mathrm{Co}^{\mathrm{en}} \gamma$-rays.

for loss of this chromosome in the surviving clones after irradiation. The cells of such clones should show a decreased radiosensitivity, owing to loss of the critical monosomic. It is possible that the radio-resistant clones isolated by Whitfield and Rixon $(12,21)$ arise in this way.

Comparison of the survival curves for L-cells with that obtained for normal (euploid) mouse bone marrow cells in vivo supports the view that euploid and heteroploid cells have different radiosensitivities. The $D_{0}$ for L-cells, 280 rads of $\mathrm{Co}^{60} \gamma$-rays, is greater by more than a factor of 2 than that obtained for normal mouse bone marrow cells (22). Qualitatively similar results have been obtained with euploid and heteroploid human cells in vitro (5). 
Though a majority of established mammalian cell lines appear to be heteroploid, it is possible to cultivate cell lines which remain diploid (23). It should be possible, by colchicine treatment, to derive tetraploid cells from such cultures. An in vitro comparison of the radiosensitivity of such tetraploid cells with that of the diploid cells from which they were derived might serve to clarify the situation.

In attempting to interpret the results presented in this paper, one further possibility must be considered. It may be that the range of chromosome numbers studied was not wide enough to allow detection of a ploidy effect. In the yeast Saccharomyces cerevisiae, the radiosensitivity decreases to a minimum value as the ploidy increases from haploid to diploid, then increases again at higher ploidies. The decrease in radiosensitivity from haploid to diploid is attributed to a decrease in the susceptibility of cells to recessive lethal damage, and the increasing radiosensitivity of cells of ploidies higher than diploid is thought to be due to the increasing importance of dominant lethal inactivation (3). It is possible that the L-cell lines studied are in a transition region where dominant and recessive lethal damages contribute

TABLE II

The Radiosensitivity of the Proliferative Capacity of Mammalian Cells

\begin{tabular}{lll}
\hline Cell designation or origin & $D_{0}\left(\right.$ or $\left.D_{37}\right)$ & Ref. \\
\hline
\end{tabular}

1. Man

Established cell cultures

HeLa S 3

$96 \mathrm{r}^{\mathrm{a}}$

Approx. $150 \mathrm{r}$

HEp 2

Same as HeLa $\mathrm{S} 3$

D $98 \mathrm{~S}$

Approx. $270 \mathrm{r}$

$\mathrm{U}-12$

Approx. 300 r $\left(D_{37}\right)$

Conjunctiva, liver, appendix

Same as HeLa $\mathrm{S} 3$

Embryonic lung

$166 \mathrm{r}^{\mathrm{a}}$

Liver

119 rads

Kidney

Recently explanted cells

Skin, spleen, ovary

Approx. $280 \mathrm{rads}\left(D_{37}\right)$

Approx. $60 \mathrm{r}^{\mathrm{a}}$

2. Chinese hamster

Ovary, lung

110-155 rads

$160 \mathrm{r}$

3. Mouse

L

280 rads

$400-450$ r $\left(D_{37}\right)$

$165 \mathrm{r}$

This work

Lymphatic leukemia ${ }^{b}$

$115 \mathrm{rads}$

a Conversion factor, roentgens to rads, 1.33 (30).

b Determined by an in vivo method. 
almost equally to inactivation, and radiosensitivity is only weakly dependent on ploidy.

There are a number of reports of dose-effect curves measured for various mammalian cell lines, either in vitro or in vivo, with colony formation as the criterion of survival of the proliferative capacity of cells after irradiation. The $D_{0}$ values obtained are listed in Table II. Some workers have reported dose-effect curves which are not of the simple multihit type. In such cases, the $D_{37}$-i.e., the dose required to give $37 \%$ survival-has been listed. It is apparent from Table II that the $D_{0}$ and the $D_{37}$ for L-cells is somewhat higher than that of most of the mammalian cell strains that have been studied. This suggests that a measurement of radiosensitivity might be helpful for the identification of L-cells, in addition to the immunological and cytological criteria now in use $(6,9)$.

\section{SUMMARY}

The radiosensitivity of the ability of strain $\mathrm{L}$ mouse cells to form macroscopic colonies has been found to be independent of chromosome number in cell lines with mean chromosome numbers between 53 and 109 chromosomes. The radiosensitivity of L-cells appears to be relatively low in comparison with values reported for other mammalian cell lines.

\section{ACKNOWLEDGMENTS}

The author wishes to thank J. Botond and T. Kruck for technical assistance, and Drs. G. F. Whitmore and L. Siminovitch for many helpful discussions. Financial support for this work was provided by a grant from the National Cancer Institute of Canada.

ReCEIved: January 3, 1961

\section{REFERENCES}

1. H. J. MULLER, The nature of the genetic effects produced by radiation. In Radiation Biology (A. Hollaender, ed.), Vol. I, Chapter 7, pp. 351-473, McGraw-Hill Book Company, New York, 1954.

2. K. C. Atwood, R. C. Von Borstel, and A. R. Whiting, An influence of ploidy on the time of expression of dominant lethal mutations in Habrobracon. Genetics 41, 804-813 (1956).

$\rightarrow$ R. K. MorTimer, Radiobiological and genetic studies on a polyploid series (haploid to hexaploid) of Saccharomyces cerevisiae. Radiation Research 9, 312-326 (1958).

4. T. T. PUCK, Action of radiation on mammalian cells. III. Relationship between reproductive death and induction of chromosome anomalies by $\mathrm{X}$-irradiation of euploid human cells in vitro. Proc. Natl. Acad. Sci. U. S. 44, 772-780 (1958).

5. T. T. PUcK, The action of radiation on mammalian cells. Am. Naturalist 94, 95-110 (1960).

6. K. H. Rothfels, A. A. Axelrad, L. Siminovitch, E. A. McCulloch, and R. C. Parker, The origin of altered cell lines from mouse, monkey, and man, as indicated by chromosome and transplantation studies. Proc. 3rd Can. Cancer Research Conf. Honey Harbour, Ontario, 1958 pp. 189-214 (1959).

7. T. C. Hsu and O. KLATT, Mammalian chromosomes in vitro. IX. On genetic polymorphism in cell populations. J. Natl. Cancer Inst. 21, 437-473 (1958).

8. K. K. SANFord, W. R. EARLE, and G. D. Likely, The growth in vitro of single isolated tissue cells. J. Natl. Cancer Inst. 9, 229-246 (1948). 
9. V. Defendi, R. E. Billingham, W. K. Silvers, and P. Moorhead, Immunological and karyological criteria for identification of cell lines. J. Natl. Cancer Inst. 25, 359-385 (1960).

10. T. C. Hsu and D. S. KellogG, JR., Mammalian chromosomes in vitro. XII. Experimental evolution of cell populations. J. Natl. Cancer Inst. 24, 1067-1093 (1960).

11. R. C. Parker, L. N. Castor, and E. A. McCulloch, Altered cell strains in continuous culture: A general survey. In Cellular Biology, Nucleic Acids and Viruses, Spec. Publ. N.Y. Acad. Sci. 5, 303-313 (1957).

12. J. F. Whitfield and R. H. Rixon, Some properties of radiation resistant derivatives of L-strain mouse cells. Exptl. Cell Research 20, 242-244 (1960).

13. D. L. Dewey, Effect of oxygen and nitric oxide on the radiosensitivity of human cells in tissue culture. Nature 186, 780-782 (1960).

14. H. B. HewitT and C. W. Wilson, The effect of tissue oxygen tension on the radiosensitivity of leukaemia cells irradiated in situ in the livers of leukaemic mice. Brit. J. Cancer 13, 675-684 (1959).

15. Report of the International Commission on Radiological Units and Measurements (ICRU) 1956. Natl. Bur. Standards (US.) Handbook No. 62 (1957).

16. T. T. Puck and P. I. Marcus, Action of X-rays on mammalian cells. J. Exptl. Med. 103, 653-666 (1956).

17. M. M. Elkind and H. Sutton, Radiation response of mammalian cells grown in culture. I. Repair of X-ray damage in surviving chinese hamster cells. Radiation Research 13, 556$593(1960)$.

18. T. T. Puck, In vitro studies on the radiation biology of mammalian cells. Progr. in Biophys. and Biophys. Chem. 10, 238-258 (1960).

19. K. Tsunewaki and E. G. Heyne, Radiological study of wheat monosomics. I. Differential sensitivity of monosomic $X$ and the disomic to X-irradiation. Genetics 44, 933-946 (1959).

20. L. Revész and U. Norman, Chromosome ploidy and radiosensitivity of tumours. Nature 187, 861-862 (1960).

21. J. F. Whitfield and R. H. Rixon, Radiation resistant derivatives of L-strain mouse cells. Exptl. Cell Research 19, 531-538 (1960).

22. J. E. Till and E. A. McCulloch, A direct measurement of the radiation sensitivity of normal mouse bone marrow cells. Radiation Research 14, 213-222 (1961).

23. T. T. Puck, S. J. Cieciura, and A. Robinson, Genetics of somatic mammalian cells. III. Long-term cultivation of euploid cells from human and animal subjects. J. Exptl. Med. 108, 945-956 (1958).

24. T. T. Puck, D. Morkovin, P. I. Marcus, and S. J. Cieciura, Action of X-rays on mammalian cells. II. Survival curves of cells from normal human tissues. J. Exptl. Med. 106, 485-500 (1957).

25. R. E. BASES, Some applications of tissue culture methods to radiation research. Cancer Research 19, 311-315 (1959).

26. S. L. Hood and G. Norris, Sensitivity of human-cell cultures to soft X-rays. Biochim. et Biophys. Acta 36, 275-278 (1959).

27. B. DjoRdjevic and W. Szybalski, Genetics of human cell lines. III. Incorporation of 5-bromo and 5-iododeoxyuridine into the deoxyribonucleic acid of human cells and its effect on radiation sensitivity. J. Exptl. Med. 112, 509-531 (1960).

28. H. Harrington, Effect of irradiation on cell division and nucleic acid synthesis in strain U-12 fibroblasts. Biochim. et Biophys. Acta 41, 461-469 (1960).

29. G. W. Barendsen, T. L. J. Beusker, A. J. Vergroesen, and L. Budke, Effects of different ionizing radiations on human cells in tissue culture. II. Biological experiments. Radiation Research 13, 841-849 (1960).

30. A. Feldman and D. Morkovin, Cell dosimetry. Radiology 74, 112-113 (1960). 